Jpn J Human Genet 42, 499-505, 1997

\title{
DNA-BASED PRENATAL DIAGNOSIS OF A KOREAN FAMILY WITH TYROSINASE-RELATED OCULOCUTANEOUS ALBINISM (OCA1)
}

\author{
Seung-Taek LeE, ${ }^{1, *}$ Sang-Kyu PARK, ${ }^{1, * *}$ Haeyul Lee, ${ }^{1}$ \\ Jin-Sung LEE, ${ }^{2}$ and Yong-Won PARK ${ }^{3}$ \\ ${ }^{1}$ Department of Biochemistry, College of Science, and Bioproducts Research Center, \\ Yonsei University, Seoul 120-749, Korea \\ ${ }^{2}$ Department of Pediatrics, and ${ }^{3}$ Department of Obstetrics and Gynecology, \\ College of Medicine, Yonsei University, Seoul 120-752, Korea
}

Summary Tyrosinase-related oculocutaneous albinism (OCA1), an autosomal recessive inborn error of pigmentation, is caused by the deficiency of tyrosinase. We had previously identified two different mutations of the TYR gene in a four year old Korean male with mild OCA; a P3I0insC frameshift in exon 2 and an IVS2-7t $\rightarrow a,-10-$ -11 deltt splice junction mutation in exon 3 . Here we report a prenatal diagnostic study of a subsequent fetus of the above family that was at $25 \%$ risk of OCA1. SSCP/heteroduplex screening, restriction enzyme digestion, and allele-specific oligonucleotide hybridization analyses of DNA obtained by chorionic villus sampling indicated that the fetus was a compound heterozygote for the paternal $\mathrm{P} 310 \mathrm{ins} \mathrm{C}$ and the maternal IVS2 $-7 \mathrm{t} \rightarrow \mathrm{a},-10--11$ deltt mutations. The diagnosis was later confirmed by observation of poorly pigmented irides of the abortus terminated at the 18th week of gestation. This approach provides a fast and reliable method for DNA-based prenatal diagnosis when specific mutations are known in families at high risk of OCAl.

Key Words genetic disease, Korean, oculocutaneous albinism (OCA), prenatal diagnosis, tyrosinase

\section{INTRODUCTION}

Oculocutaneous albinism (OCA) is an autosomal recessive genetic disorder characterized by deficient biosynthesis of melanin pigment in the skin, hair

Received July 11, 1997; Accepted August 11, 1997.

* To whom correspondence should be addressed: Department of Biochemistry, College of Science, Yonsei University, Seoul 120-749, Korea.

** Present address: Research and Development Center, Dae-Woong Pharmaceutical Co., Sungnam, Kyunggi-Do 462-120, Korea. 
follicle, and eyes (Witkop et al., 1989; Spritz, 1994; Spritz and Hearing, 1994). Patients affected with OCA typically exhibit reduced visual acuity with nystagmus, strabismus, and photophobia, and extremely fair skin complexion with a high risk of skin cancers due to actinic damage. In addition, OCA patients are often socially handicapped due to their appearance, especially in non-Caucasian populations. The prevalence of OCA is about I per 16,000-20,000 individuals in the United States (Witkop et al., 1989) and in Japan (Shimizu et al., 1994a).

Several types of OCA have been described, resulting from mutations in three distinct loci; OCA1 is associated with the TYR gene (Tomita et al., 1989; Spritz, 1994), OCA2 is associated with the $P$ (pink-eyed dilution) gene (Rinchik et al., 1993; Lee et al., 1994), and OCA 3 is associated with the TYRP-l gene (Boissy et al., 1996). Among these, OCAl is associated with deficient activity of melanocyte tyrosinase which catalyzes the rate-limiting steps of the melanin biosynthesis (Lerner and Fitzpatrick, 1950; Lerner et al., 1949; Tripathi et al., 1992). In OCA1A (tyrosinase-negative OCA1), tyrosinase activity is completely absent (Tripathi et al, 1992; Tomita et al., 1989), whereas in OCA1B (yellow OCA1) tyrosinase activity is greatly reduced (Giebel et al, 1991a). OCA1B thus tends to be clinically less severe than OCAlA, though there is virtual overlap between the associated clinical phenotypes. Prenatal diagnosis of OCA has been accomplished by evaluating fetal skin obtained by biopsy (Eady et al., 1983; Eady, 1984; Gershoni-Baruch et al., 1991; Shimizu et al., 1992, 1994b) or by analyzing the TYR gene in fetal DNA obtained by aminiocentesis (Shimizu et al., 1994a; Falik-Borenstein et al., 1995).

We have recently identified six different mutations of the TYR gene in the 9 Korean patients with OCAl (Park et al, 1996; Park et al., 1997). One of these patients exhibited OCA IB associated with a P310insC frameshift (CCA $\rightarrow$ CCCA) and an IVS2 $-7 t \rightarrow a,-10--11$ deltt splice junction mutation (ttttaatgaacagGA $\rightarrow$ tttaaagaacagGA) of the TYR gene (Park et al., 1997). Recently, this patient's parents requested prenatal diagnosis for their second pregnancy. Here, we report the diagnosis of OCA1B in that fetal sample, obtained by chorionic villus sampling (CVS) at 10th week of gestation. This approach provides a fast, safe, and reliable method for prenatal diagnosis at a very early stage in gestation in families at elevated risk for OCAI and other genetic disorders.

\section{MATERIALS AND METHODS}

Chorionic villus sampling. A Korean couple had a 4-year-old son with OCA1B. Molecular analysis of the $T Y R$ gene demonstrated that the proband was a compound heterozygote for a P310insC frameshift in exon 2 and an IVS2 $-7 t \rightarrow$ a, -10--11deltt splice junction mutation in adjacent to exon 3 (Park et al., 1997). The mother was in her second pregnancy and was referred for prenatal diagnosis of OCA. For prenatal diagnosis, CVS was performed at the 10th week of gestation 
and the fetal tissue was dissected to remove maternal decidua.

$P C R$ amplification of the human TYR gene. Genomic DNA was isolated from the CVS sample and from peripheral-blood leukocytes of the proband, the parents, and unrelated normal controls (Sambrook et al, 1989). The TYR exon 2 and 3 segments containing the $T Y R$ mutations in the proband were amplified from the genomic DNAs by the polymerase chain reaction (PCR) using as primers $5^{\prime}$-CCTCAGGAGAAGTCTAACAAC-3' $/ 5^{\prime}$-ACAACACATATTCTTGGTC-3' (exon 2) and $5^{\prime}$-TGGGTATCCAGAATGTAAA-3' $/ 5^{\prime}$-TTTAAATCCAATGAGCACG-3' (exon 3) (Giebel et al., 1991b; Park et al., 1997) and Taq DNA polymerase (Perkin Elmer, USA) as described (Saiki et al., 1988; Park et al., 1997).

DNA-based prenatal diagnosis. The amplified exon segments were analyzed by two different methods. First, the presence of the specific mutations in fetal sample was tested by non-radioactive simultaneous analyses of SSCPs and heteroduplexes (Lee et al., 1995) using MDE gel (FMC BioProducts, USA).

Heterozygosity for the P310insC frameshift was confirmed by allele-specific oligonucleotide (ASO) hybridization (Saiki et al., 1986). Two hundred nanograms of the exon 2 PCR products were applied to a nylon membrane (Micron Separation Inc., USA) using a slot blot apparatus (Hoefer Scientific Instrument, USA). Nineteen-mer oligonucleotides including the normal P310 (5'-CCAGACCCCAAGGCTCCC-3') and mutant P310insC (5'-CCAGAACCCCCAAGGCTCC-3') were labeled at the $5^{\prime}$-end by $\mathrm{T} 4$ polynucleotide kinase. The nylon membranes were prehybridized and hybridized at $37^{\circ} \mathrm{C}$ in $5 \times$ SSPE, $5 \times$ Denhardt's solution, and $0.5 \% \mathrm{SDS}$, and washed at $60^{\circ} \mathrm{C}$ in $3 \mathrm{M}$ tetramethylammonium chloride, $50 \mathrm{mM}$ Tris- $\mathrm{HCl}$ ( $\mathrm{pH} 8.0$ ), $2 \mathrm{mM}$ EDTA, and $0.1 \%$ SDS before autoradiography.

The IVS2 $-7 \mathrm{t} \rightarrow \mathrm{a},-10--11$ deltt mutation generates a novel DraI restriction enzyme cleavage site. Heterozygosity for this mutation was thus confirmed by DraI digestion of the exon 3 PCR products and electrophoresis in 5\% polyacrylamide gel.

\section{RESULTS AND DISCUSSION}

We have carried out prenatal diagnosis of OCA in the pregnancy of parents with a previous child with OCA1B resulting from compound heterozygosity for a P310insC frameshift and a splice junction mutation, IVS2 $-7 \mathrm{t} \rightarrow \mathrm{a},-10--11 \mathrm{deltt}$ (Park et al., 1997). The risk of the OCA1B in the fetus was $25 \%$. We utilized two different DNA-based approaches to detect each mutation.

The presence of the $\mathrm{P} 310$ ins $\mathrm{C}$ mutation in the fetal sample was first determined by SSCP/heteroduplex analysis of the TYR exon 2 PCR products. The sample from the proband who was heterozygous for the P310ins $C$ mutant allele demonstrated an aberrant band in the fast-migrating duplex region (Fig. 1A). The abberrant band was also detected in the lanes of the father and the fetus, but not in the lane of the mother (Fig. 1A). The fetus was thus heterozygous for a paternal P310ins $C$ mutant allele.

Vol. 42, No. 4, 1997 
A

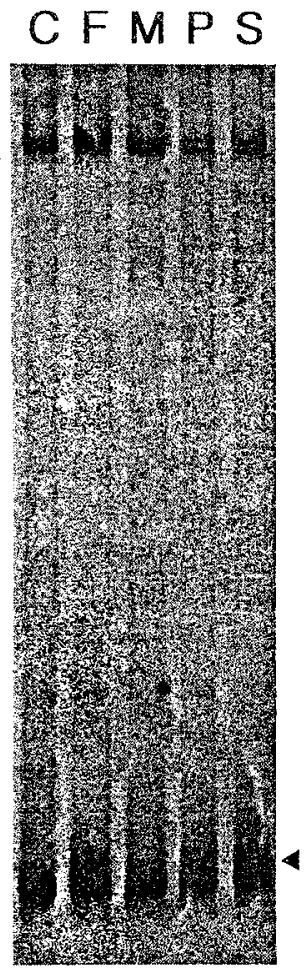

B

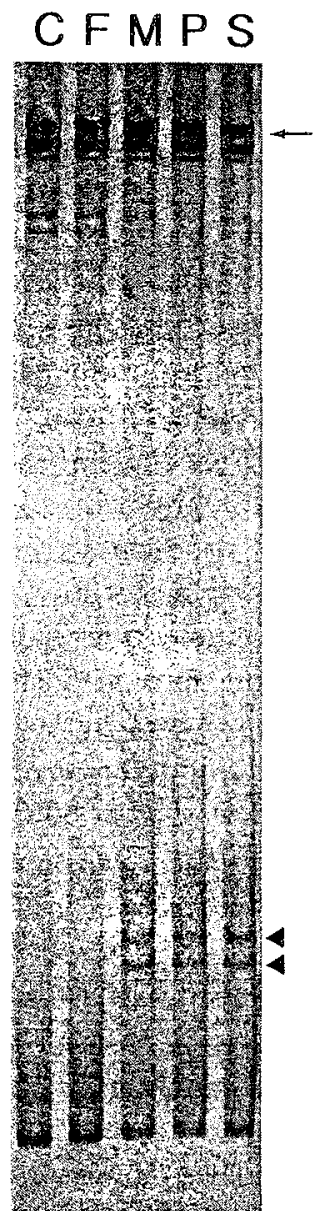

Fig. 1. Analysis of the P310insC frameshift (A) and the IVS2t $\rightarrow a,-10--11$ deltt mutation (B) by simultaneous SSCP and heteroduplex detection. Lanes C, a normal control; $F$, the father; $M$, the mother; $P$, the proband affected with OCA $1 B ; S$, the fetal sample under study. A heteroduplex band characteristics of the P3l0insC frameshift is marked as an arrowhead in the A panel. An SSCP band and heteroduplex bands characteristics of the IVS2t $\rightarrow a,-10-$ - lidelt mutation are marked as an arrow and arrowheads in the B panel, respectively.

Heterozygosity for the P310insC frameshift in the fetus was further determined by ASO hybridization analysis using the P310 normal and the P310insC mutant oligonucleotides. As shown in Fig. 2, the exon 2 PCR products from the father, the 


\section{Mutant}

\section{Normal}

\section{F M P S}

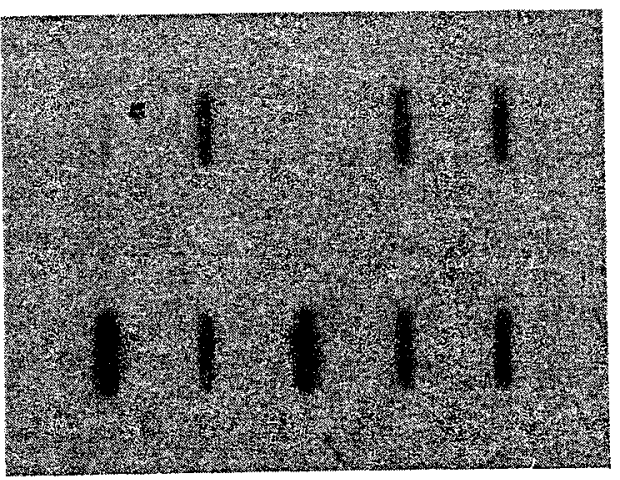

Fig. 2. Analysis of the P310insC frameshift by ASO hybridization. The upper panel and the lower panel show slot blot hybridization with the probes specific for the sequence containing the P310insC frameshift (Mutant) and for the normal sequence (Normal), respectively. Lanes $\mathrm{C}-\mathrm{S}$, same as lanes in Fig. 1.

proband, and the fetus were hybridized with both mutant and normal oligonucleotides, whereas the exon 2 PCR products from the mother and a normal control were hybridized only with the normal oligonucleotide. The fetus was thus confirmed to be heterozygous for the P310insC frameshift.

The presence of the IVS2-7t $\rightarrow a,-10--11$ deltt mutation in the fetal sample was also determined by SSCP/heteroduplex analysis of the TYR exon 3 PCR products. The sample from the proband who was heterozygous for the IVS2 $-7 \mathrm{t} \rightarrow$ a, -10-11deltt mutant allele demonstrated aberrant bands in both slowmigrating single-strand and fast-migrating duplex regions (Fig. 1B). The abberant bands were also detected in the lanes of the mother and the fetus, but not in the lanes of the father and a normal control (Fig. 1B). The fetus was thus heterozygous for a maternal IVS2 $-7 \mathrm{t} \rightarrow \mathrm{a},-10--11$ deltt mutant allele.

Because the IVS2 $-7 \mathrm{t} \rightarrow \mathrm{a},-10--11$ deltt splice junction mutation generates a novel DraI restriction enzyme site, heterozygosity for the IVS2-7t $\rightarrow \mathrm{a},-10$ -11 deltt mutation in the fetus was further determined by digestion with restriction enzyme DraI. Whereas the 356-bp exon 3 PCR products from the father and a normal control were not cleaved by DraI digestion, a half amount of the exon 3 PCR products from the mother, the proband, and the fetus were cleaved to the 202-bp and 152-bp fragments (Fig. 3). The fetus was thus confirmed to be heterozygous for the IVS2 $-7 \mathrm{t} \rightarrow \mathrm{a},-10--11$ deltt mutation.

Because we obtained consistent results in two independent analyses for each $T Y R$ mutation, we concluded that the fetus was a compound heterozygote for the $\mathrm{P} 310$ ins $\mathrm{C}$ frameshift and the IVS2 $-7 \mathrm{t} \rightarrow \mathrm{a},-10--11$ deltt splice junction mutation. Therefore, the fetus was expected to exhibit OCA IB as same as the proband. The 


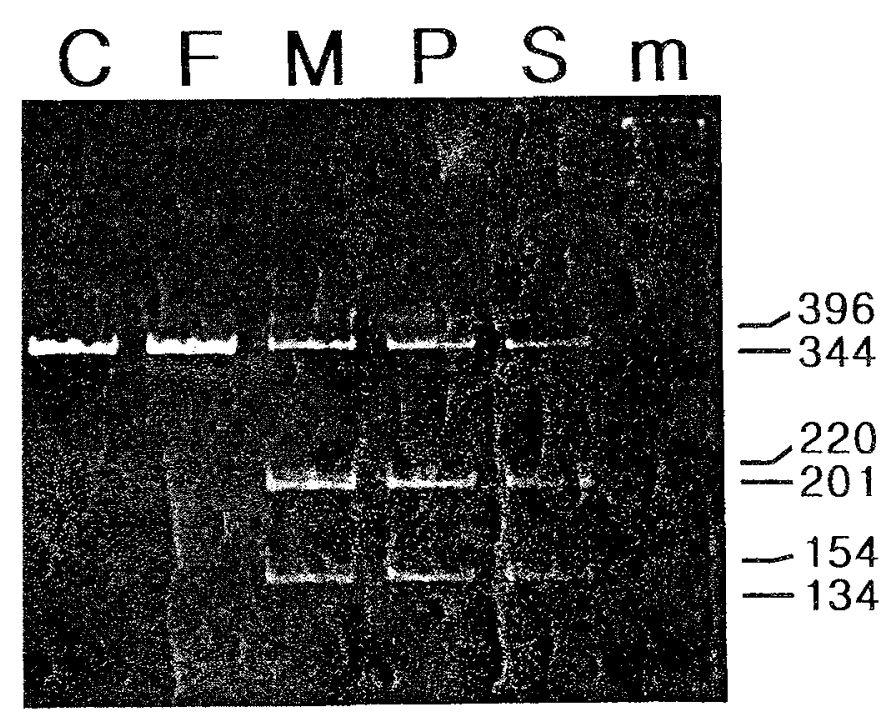

Fig. 3. Analysis of the IVS2 $t \rightarrow a,-10--11$ deltt mutation by Dral digestion. The IVS2 $t \rightarrow a,-10--11$ delt mutation generates a Dral site. By Dral digestion, the 354-bp mutant exon 3 allele cleaves to the 202-bp and 152-bp fragments but the 356-bp normal exon 3 allele remains intact. Lanes C-S, same as lanes in Fig. I; $\mathrm{m}$, a molecular size marker (Gibco BRL Life Technologies Inc.).

parents decided to terminate the prenancy at the 18 th week of gestation. The prenatal diagnosis was confirmed by observation of poorly pigmented irides of the abortus.

We have shown that OCAI can be diagnosed using fetal cells obtained by CVS at the 10th week of pregnancy using simple DNA-based approaches such as non-radioactive simultaneous SSCP/heteroduplex analysis, restriction enzyme cleavage, and ASO hybridization. These results would provide a fast and accurate procedure for prenatal diagnosis of OCA1 and other genetic diseases.

Acknowledgments This work was supported by a grant from KOSEF (\#971-0708-066-2). We wish to thank Dr. R.A. Spritz (University of Wisconsin-Madison, USA) for critical reading of the manuscript.

\section{REFERENCES}

Boissy RE, Zhao H, Oetting WS, Austin LM, Wildenberg SC, Biossy YL, Zhao Y, Sturm RA, Hearing VJ, King RA, Nordlund JJ (1996): Mutation in and lack of expression of tyrosinaserelated protein-1 (TRP-1) in melanocytes from an individual with brown oculocutaneous albinism: a new subtype of albinism classified as "OCA3." Am J Hum Genet 58: 1145-1156

Eady RAJ (1984): Prenatal diagnosis of oculocutaneous albinism. Implications for other hereditary disorders of pigmentation. Semin Dermatol 3: $241-246$

Eady RAJ, Gunner DB, Tidman MT, Nicolaides KH, Rodeck DH (1983): Prenatal diagnosis of oculocutaneous albinism by electron microscopy of fetal skin. J Invest Dermatol 80: 210-212

Falik-Borenstein TC, Holmes SA, Borochowitz Z, Levin A, Rosemann A, Spritz RA (1995): DNA-based carrier detection and prenatal diagnosis of tyrosinase-negative oculocutaneous albinism (OCA1A). Prenatal Diagn 15: 345-349 
Gershoni-Baruch R, Benderly A, Brandes JM, Gilhar A (1991): DOPA reaction test in hairbulbs of fetuses and its application to the prenatal diagnosis of albinism. J Am Acad Dermatol 24: 220-222

Giebel LB, Tripathi RK, Strunk KM, Hanifin JM, Jackson CE, King RA, Spritz RA (1991a): Tyrosinase gene mutations associated with type IB ("yellow") oculocutaneous albinism. Am J Hum Genet 48: 1159-1167

Giebel LB, Strunk KM, Spritz RA (1991b): Organization and nucleotide sequences of the human tyrosinase gene and a truncated tyrosinase-related segment. Genomics 9: 435-445

Lee S-T, Strunk KM, Bundey S, Laxova R, Musarella M, Spritz RA (1994): Mutations of the $P$ gene in oculocutaneous albinism, ocular albinism, and Prader-Willi syndrome plus albinism. $\mathrm{N}$ Eng J Med 330: 529-534

Lee S-T, Park S-K, Lee K-H, Holmes SA, Spritz RA (1995): A non-radioactive method for simultaneous detection of single-strand conformation polymorphisms (SSCPs) and heteroduplexes. Mol Cells 5: 668-672

Lerner AB, Fitzpatrick TB (1950): Biochemistry of melanin formation. Physiol Rev 30: 91-126

Lerner AB, Fitzpatrick TB, Calkins E, Summerson WH (1949): Mammalian tyrosinase: preparation and properties. J Biol Chem 178: 185-195

Park KC, Park S-K, Lee YS, Youn SW, Park BS, Kim KH, Lee S-T (1996): Mutations of the tyrosinase gene in three Korean patients with type I oculocutaneous albinism. Jpn J Human Genet 41: 299-305

Park S-K, Lee K-H, Park K-C, Lee J-S, Spritz RA, Lee S-T (1997): Prevalent and novel mutations of the tyrosinase gene in Korean patients with tyrosinase-deficient oculocutaneous albinism. Mol Cells 7: 187-191

Rinchik EM, Bultman SJ, Horsthemke B, Lee S-T, Strunk KM, Spritz RA, Avidano KM, Jong MTC, Nicholls RD (1993): A gene for the mouse pink-eyed dilution locus and for human type II oculocutaneous albinism. Nature 361: 72-76

Saiki RK, Bugawan TL, Horn GT, Mullis KB, Erlich HA (1986): Analysis of enzymatically amplified beta-globin and HLA-DQ alpha DNA with allele-specific oligonucleotide probes. Nature 324: $163-166$

Saiki RK, Gelfand DH, Stoffel S, Scharf SJ, Higuchi R, Horn GT, Mullis KB, Ehrlich HA (1988): Primer directed enzymatic amplification of DNA with a thermostable DNA polymerase. Science 239: 487-49!

Sambrook J, Fritsch EF, Maniatis T (1989): Molecular cloning: A laboratory manual. 2nd ed. Cold Spring Harbor Press, Cold Spring Harbor

Shimizu H, Ishiko A, Kikuchi A, Akiyama M, Suzumori K, Nishikawa T (1992): Prenatal diagnosis of tyrosinase-negative oculocutaneous albinism. Lancet 340: 739-740

Shimizu H, Niizeki H, Suzumori K, Aozaki R, Kawaguchi R, Hikiji K, Nishikawa T (1994a): Prenatal diagnosis of oculocutaneous albinism by analysis of the fetal tyrosinase gene. $J$ Invest Dermatol 103: 104-106

Shimizu H, Ishiko A, Kikuchi A, Akiyama M, Suzumori K, Nishikawa T (1994b): Prenatal diagnosis of tyrosinase-negative oculocutaneous albinism by an electron microscopic dapa reaction test of fetal skin. Prenatal Diagn 14: 443-450

Spritz RA (1994): Molecular genetics of oculocutaneous albinism. Hum Mol Genet 3: 1469-1475

Spritz RA, Hearing VJ Jr (1994): Genetic disorders of pigmentation. Adv Hum Genet 22: 1-45

Tomita Y, Takeda A, Okinaga S, Tagami H, Shibahara A (1989): Human oculocutaneous albinism caused by single gene insertion in the tyrosinase gene. Biochem Biophys Res Commun 164: 990-996

Tripathi RK, Hearing VJ, Urabe K, Aroca P, Spritz RA (1992): Mutational mapping of the catalytic activities of human tyrosinase. J Biol Chem 267: 23707-23712

Witkop CJ Jr, Quevedo WC Jr, Fitzpatrick TB, King RA (1989): Albinism and the disorders of pigment metabolism. In: Scriver CR, Beaudet AL, Sly WS, Valle D (eds). The metabolic basis of inherited disease. 6th ed. McGraw-Hill, New York, pp 2905-2947 